\title{
Assessment of Roadside Particulate Emission Mitigation Possibilities
}

\author{
Dzintra Slisane ${ }^{1}$, Dagnija Blumberga ${ }^{2},{ }^{1-2}$ Riga Technical University
}

\begin{abstract}
The improvement of air quality is now an issue for all developed countries. In the European Union transportation is the main source of NOx pollution and the second most significant PM10 and PM2, 5 emission sources. The focus of the research is transportation PM10 emissions. The paper introduces a model of system dynamics for analysis of road transportation PM10 emissions. The developed model is then used to compare PM10 emissions in 4 cases, one of which is the baseline, while in the other 3 a variety of road transport emission reduction methods are implemented. The simulation results have shown that the highest daily PM10 emission reductions can be achieved by combining technological and administrative methods. Administrative methods (rush-hour driving tax and heavy vehicle traffic restrictions) turned out to be the most effective.
\end{abstract}

Keywords - canyon type streets, PM10 concentration, system dynamic, urban air quality, vehicle $\mathbf{P M}_{10}$ emissions.

\section{INTRODUCTION}

In Europe the number of cars is increasing every year, cargo operations are dominated by road transportation. In the Baltic States (Lithuania, Estonia and Latvia) long-distance transport is well developed -in these countries accordingly $70 \%, 73 \%$ and $85 \%$ of freight is delivered by road. It is one of the most influential sectors in many aspects; one of them is environmental impact. The main environmental impacts of transportation are GHG emissions, increased noise levels and air quality deterioration. [1]

Transportation is the main source of $\mathrm{PM}_{10}$ and $\mathrm{PM}_{2.5}$ emissions in European Union (EU). Particulate matter due to its diminutive dimensions is capable of penetrating deep into the human respiratory system and can cause serious harm to human health. According to the World Health Organization, living in the most polluted cities and regions can reduce a person's life expectancy by about two years. To protect human health, the European Union has set air quality standards for $\mathrm{PM}_{10}$ and finer particle $\mathrm{PM}_{2.5}$ fractions, but in many countries, including Latvia, pollution concentration exceeds these standards.[2] Although direct $\mathrm{PM}_{10}$ and $\mathrm{PM}_{2.5}$ emissions have receded by $14 \%$ in EU and $15 \%$ in 32 EEA countries over the time period from 2001 till 2010, part of the urban population (18-41\% of the EU-15 and $23-41 \%$ of the EEA-32) are still exposed to high levels of $\mathrm{PM}_{10}$ concentrations, exceeding EU regulated thresholds.[3] Air quality standards in Latvia determe that the $\mathrm{PM}_{10}$ concentration threshold for human health is a daily average of $50 \mu \mathrm{g} / \mathrm{m} 3$ which should not be exceeded for more than 35 days a year. According to the Latvian Environment, Geology and Meteorology Centre data from a measurement station in Riga (Brīvibas 73), these conditions have been breached for the past 5 years. The use of sand-salt mixture and studded tires during the winter contributes to excess $\mathrm{PM}_{10}$ concentration in several countries including Latvia.

Particulate matter pollution mainly consists of minerals: silicates, carbonates, oxides, phosphates. Vehicle emissions contain heavy metals $(\mathrm{Pb}, \mathrm{Cd}, \mathrm{As}, \mathrm{Ni})$ and black carbon. Dimensions of mineral particles are usually between $2,5 \mu \mathrm{m}$ and $10 \mu \mathrm{m}\left(\mathrm{PM}_{10-2,5}\right)$. Mineral particles in fraction $\mathrm{PM}_{2,5}$ occur more as a result of mechanical abrasion. Tire wear is the main source of organic compound particles. [4]

When a vehicle is in motion $\mathrm{PM}_{10}$ emissions are produced by car exhaust fumes, tire wear from contact with pavement surface, brake disc wear, road surface wear and particle resuspension. Exhaust gases contain carbon monoxide, nitrogen oxides, hydrocarbons, and are distinguished in fine and ultra fine fraction of PM particles. Studies have shown that the exhaust emissions are generally with particle size less than $1 \mu \mathrm{m}$. It is believed that the exhaust from internal combustion engines account for about $15 \%$ of the daily average of $\mathrm{PM}_{10}$ concentrations. [5] The reduction of $\mathrm{PM}_{10}$ emissions from exhaust gases is a responsibility of vehicle and fuel producers. It was proved that the greatest part (depending on the measurement site about $50-85 \%$ ) of transport $\mathrm{PM}_{10}$ emissions are not produced by car exhaust. Therefore, it is significant to evaluate the mechanical abrasion $\mathrm{PM}_{10}$ emissions resulting from the interaction between the road and the vehicle and find solutions to reduce them. [6] Particulate emissions from tire wear are dependent on various factors: tire physical and chemical properties, type (summer, winter, with / without spikes), surface properties (gravel/asphalt, asphalt type, surface roughness and surface maintenance), road surface management practices (cleaning, watering, spreading in winter), weight of the vehicle (passenger cars, commercial vehicles, etc.), speed and driving style, weather conditions. The studies on tire quality (including wear factors) are often made by producers themselves in order to create qualitative products with the lowest possible cost. Tire manufacturers today are, at least in words, trying to find sustainable and environmentally friendly solutions.

Abrasion resulting from tire material differs in size, shape and composition. It consists primarily of PAHs, elemental carbon and organic carbon.[7] $\mathrm{PM}_{10}$ emissions from tire wear are studied in a number of scientific institutes. [6,7,9] Testing is carried out in both laboratory and field conditions. There are different simulators for evaluating tire wear in laboratories. The Swedish National Road and Transport Institute use the circular road simulator [9]. It is constructed so that tires move in a circle which is laid with selected coverage. The speed of the simulator can be varied from $0-70 \mathrm{~km} / \mathrm{h}$, the type of 
vehicle can be chosen depending on the purpose of the research. This plant has shown an effective correlation between the tire wear in real conditions on the road and the simulator. The factors of tire wear emission can be determined using this kind of simulator. Brake wear is often discussed together with other characteristics of the vehicle, for example, tire wear or exhaust emissions.[6] Road surface properties are also an important factor. The road surface must withstand traffic flow intensity and natural factors (changes in temperature, water exposure).

The research is based on $\mathrm{PM}_{10}$ concentration in urban environment, where most commonly used road coverage materials are asphalt concrete (AC), stone mastic asphalt (SMA) and porous asphalt (PA). During research carried out in Norway, the relationship between road surface and formation of PM particles was determined: the lower aggregate roughness and common Nordic abrasion value, the less PM particles are formed. Damaged road surfaces increase $\mathrm{PM}_{10}$ emissions.[9] There are $72440 \mathrm{~km}$ of roads in Latvia, the road network density is $1,122 \mathrm{~km} / \mathrm{km} 2$. $14707 \mathrm{~km}$ of roads are covered with asphalt. More than $27 \%(2306 \mathrm{~km})$ of them can be classified as outdated and being in need of complete reconstruction. Requirements for the quality of road and pavement in Latvia are determined by "Road Specifications 2012" that have been developed in line with European standards.

A study in Germany has found that $40-50 \%$ of $\mathrm{PM}_{10}$ emissions from transport are directly attributable to particle resuspension. Particulate matter deposited on road surface lifts up from the turbulent air flows caused by vehicle movement. On highways with heavy traffic PM re-suspension is mainly caused by heavy vehicles.[6]

Transportation PM10 emissions are directly dependent on the intensity of road traffic. The correlation between PM10 concentration and vehicular traffic intensity can be seen in Table 1, which contains data from 3 air PM10 concentration observation stations situated in Riga. PM re-suspension at these sites were calculated as

$$
E_{P M}=E_{T P M} \times\left(\frac{\Delta C_{P M}}{\Delta C_{T P M}}\right)
$$

where

$\mathrm{E}_{\mathrm{PM}}$ - re-suspended emissions

$\mathrm{E}_{\mathrm{TPM}}$-- theoretically calculated emission index

$\Delta \mathrm{C}_{\mathrm{PM}}-\mathrm{PM}$ concentration change near the road

$\Delta \mathrm{C}_{\mathrm{TPM}}$ - theoretically calculated PM concentration change near the road

$\mathrm{PM}_{10}$ emissions from transportation are closely related to technological means used for road maintenance. The Latvian winter maintenance season is almost half a year - from the 1 November until 31 March. Salt mixture with sand or gravel is traditionally used as the anti-slip material in order to increase the pavement surface coefficient of adhesion in winter conditions. Observations indicate that 2.5 hours after a dry road sanding $\mathrm{PM}_{10}$ concentration increases by $75 \%$ and about 8 hours after spreading $\mathrm{PM}_{10}$ emissions back to previous levels. [11] However, dust particles are still deposited on the road surface and can be re-suspended.

TABLEI

TrafFic Volume AND CONCENTRATION OF PM $\mathrm{PM}_{10}$ In 3 OBSERVATION POINTS IN RIGA [10]

\begin{tabular}{|c|c|c|c|}
\hline $\begin{array}{c}\text { Observational } \\
\text { station }\end{array}$ & $\begin{array}{c}\text { Traffic intensity, } \\
\text { vehicles / day }\end{array}$ & $\begin{array}{c}\text { The observed } \\
\text { value, } \\
\mu \mathrm{g} / \mathrm{m} 3\end{array}$ & $\begin{array}{c}\text { Re- } \\
\text { suspension } \\
\%\end{array}$ \\
\hline Brīvības street & 25400 & 52,55 & 36 \\
\hline $\begin{array}{c}\text { Kr.Valdemāra } \\
\text { street }\end{array}$ & 18530 & 45,02 & 25 \\
\hline $\begin{array}{c}\text { S.Eizenšteina } \\
\text { street }\end{array}$ & 8654 & 32,49 & 22 \\
\hline
\end{tabular}

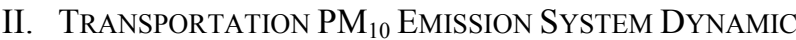
MODEL

The air quality problem in street canyons has been approached using different modeling techniques like composite lattice Boltzmann model [16] or WinOSPM [17]. These techniques are mathematical, while the dynamics method of the systems includes causal loop diagrams, which display the structure of the systems and components in a more transparent manner that helps to achieve the aim of this study more effectively.

$\mathrm{PM}_{10}$ concentration in the immediate vicinity of the road depends on a number of factors; it is a complex system that is also constantly re-suspending dust particles deposited on the road surface. A tool, which is used to demonstrate the relationship between the various system parameters (the amount of light and heavy vehicles, building height, driving speed, etc.), is necessary to understand the behavior of such a system, predict possible changes and test $\mathrm{PM}_{10}$ mitigation options. The system dynamic methodology can provide such a tool. The models of system dynamics have been used to analyze various complex systems for over 50 years. JW Forrester can be considered as the "father" of system dynamics. He began to use computer simulations for social system analysis in the middle of the 20th century. The introduced method was later named system dynamics and became an important aid for decision-making in diverse fields. System dynamics can be used for both technical and socioeconomic systems. It is widely used in environment-related fields, such as waste management, energy, environmental sociology. [13] [14][15]

The system is a set of elements where components interact with each other and cause significant system behavior. System dynamics make it possible to describe these different elements as components of the united system. The method is based on system behavior and the structure exploration in search of regularities and relationships between components. It is based on three key concepts:

- $\quad$ stocks, flows, and feedback;

- $\quad$ well-defined system boundaries;

- causation, not correlation.

The structure of the model is represented as a stock - flow diagram. The stock - flow diagram consists of four types of 
elements: stocks, flows, parameters and links (see Figure 1). The stock is the amount that accumulates over time; the flow shows the changes in accumulation speed.

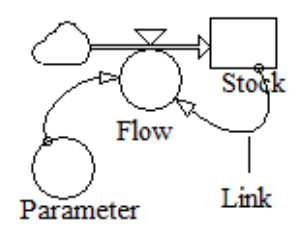

Fig. 1. Basic elements of stock-flow diagram

Additional parameters usually contain equations or constants that influence flow. Figure 1 represents a positive incoming flow, which increases the value of the stock. The outflow "flows" out from the stock reducing its value. The link performs data transfer function.

\section{DEVELOPMENT OF THE MODEL}

The model of the developed transport $\mathrm{PM}_{10}$ emission consists of one stock (PM10_emissions_in_air) with the outgoing and incoming flow. The stock accumulates the amount of airborne $\mathrm{PM}_{10}$ in grams per $1 \mathrm{~km}$ street. The input flow shows the rate of PM formation $(\mathrm{g} / \mathrm{h})$ which is influenced by four main factors:

- vehicle exhaust emissions

- tire and brake wear,

- coverage influence factor

- re-suspension.

The outflow is $\mathrm{PM}_{10}$ settling. $\mathrm{PM}_{10}$ concentration is calculated by dividing the quantity of $\mathrm{PM}_{10}$ in the air $(\mathrm{g})$ by street notional volume. The notional volume of the street is calculated by multiplying the average height of buildings on the street with the width and length of the street (in this case $1000 \mathrm{~m}$ ). The developed model can be used only for canyon type streets and roads. The structure of the transport $\mathrm{PM}_{10}$ emission models is illustrated in Figure 2.

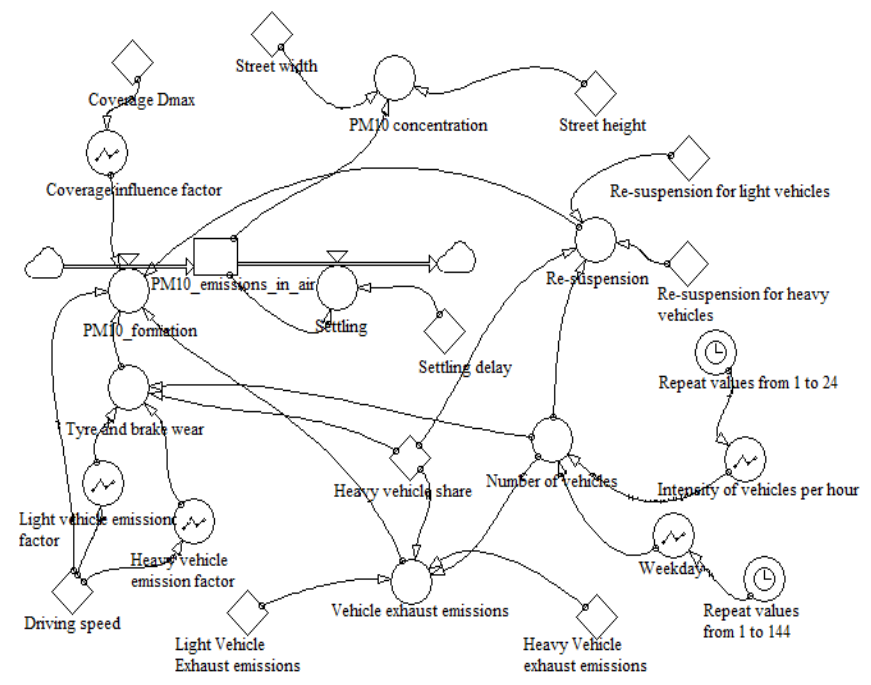

Fig.2. Transportation PM10 emission models structure
The vehicle exhaust emissions from tire and brake wear, coverage influence factor and re-suspension are dynamic values that vary depending on vehicle driving speed, traffic intensity and share of heavy vehicles. $\mathrm{PM}_{10}$ emissions are also influenced by wind speed, air humidity, etc. factors independent from human action, which are not included in the model.

\section{PARAMETERS AND ASSUMPTIONS}

$\mathrm{PM}_{10}$ concentration in the air is calculated using following formula:

$$
C_{P M 10}=C_{P M 10}(t+d t)+\text { Formation }(t)-\operatorname{Settlig}(t)
$$

Where:

$\mathrm{C}_{\mathrm{PM} 10}-\mathrm{PM}_{10}$ concentration in air

$\mathrm{C}_{\mathrm{PM} 10}(\mathrm{t}+\mathrm{dt})$ - previously accumulated $\mathrm{PM}_{10}$ concentration

As already stated, the main factors which influence $\mathrm{PM}_{10}$ concentration in the air on the road are: vehicle exhaust gases, tire and brake wear, road surface wear and particle resuspension. These factors depend on road traffic intensity (number of vehicles), as well as the speed and type of vehicle (light and heavy vehicles).

$$
\text { Formation }=A * k+B+C
$$

Where:

A - tire and break wear;

$\mathrm{B}$ - exhaust gas emissions;

C - re-suspension;

$\mathrm{k}$ - road surface influence factor

Part of road transport $\mathrm{PM}_{10}$ emissions come from brake and tire wear. This variable parameter is affected by four subparameters - emission factor for light vehicles, emission factor for heavy vehicles, number of vehicles and share of heavy vehicles. Break and tire wear emission values used in the developed model were taken from the project "Guideline development for preparation of vehicle-related $\mathrm{PM}_{10}$ and $\mathrm{PM}$ 2,5 modeling in Latvian conditions" report and European Monitoring and Evaluation Programme „EMEP/CORINAIR Emission Inventory Guidebook - 2007', Break and tire wear emissions vary depending on driving speed of the vehicle (see Figure 3).
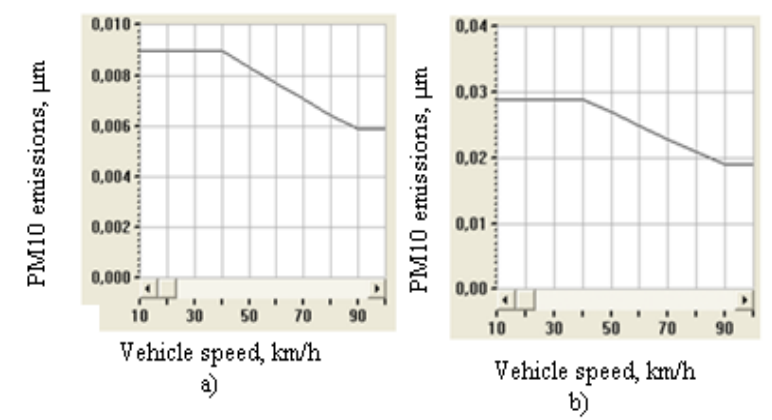

Fig. 3. $\mathrm{PM}_{10}$ emissions from a) light and b) heavy vehicle 
In order to include the option of different road surfaces, which could prove to be useful in further research, tire wear emissions in the developed model are multiplied by coverage influence factor. The abrasion factor for new asphalt is 0,024 $\mathrm{mg} / \mathrm{km}$ per passenger vehicle. This figure includes both tire and road surface wear. The particle size distribution shows that the surface wear is negligible $(<10 \%)$. [6] More significant is the effect of asphalt surface roughness on tire wear. The best parameter to characterize surface roughness is maximum aggregate particle diameter $\left(D_{\max }\right)$. Road coverage influence factor for SMA 8 (Tone mastics asphalt) coverage is assumed to be 1. According to Snilsberg B., Myran T. and Uthus $N$. road coverage impact increases with increasing $\mathrm{D}_{\max }$. (SMA 12 impact factor is 1.25; SMA $\left.16-1,5\right)$ [9]

Emissions from a vehicle's exhaust gas are composed of four parameters: number of vehicles (units / hr), share of heavy vehicles (\%), exhaust emissions from light vehicle and exhaust emissions from heavy vehicle ( $g$ per vehicle per $\mathrm{km}$ ). Recorded vehicles in running order in Latvia are on average 12.3 years old. Most cars use gasoline engines. Vehicle emission factors used in this model were calculated using data from Yan Fang et al. research on fuel combustion PM10 emissions. [12] It was assumed that the average fuel consumption per vehicle on $100 \mathrm{~km}$ is 8 liters $(0.08$ liters per $\mathrm{km})$. It was obtained that a light vehicle creates on average $0.0034 \mathrm{mg} \mathrm{PM} \mathrm{PM}_{10}$ emissions per $1 \mathrm{~km}$. Heavy vehicle on 100 $\mathrm{km}$ creates on average $0.00102 \mathrm{mg}$ of $\mathrm{PM}_{10}$ per $\mathrm{km}$.

Re-suspension depends on traffic intensity and share of heavy vehicles. Re-suspension emission factors are $0.9 \mathrm{~g} / \mathrm{km}$ for light vehicles and $2,7 \mathrm{~g} / \mathrm{km}$ for heavy vehicles.

The model operates under the assumption that $\mathrm{PM}_{10}$ settling is only influenced by the force of gravity. Weather data (wind speed and direction, rain, ambient temperature and others) are not taken into account. Time delay for PM10 settling time is $5.475 \mathrm{~h}$, which was calculated from the average settling time given by Dahl E [17]. Driving speed is assumed to be equal to the city speed limit in Latvia $-50 \mathrm{~km} / \mathrm{h}$. The simulation is carried out for a canyon type street with specific characteristics (street width, the notional volume of traffic) from the street Brivibasin Riga. The selected time of the simulation is one day $(24 \mathrm{~h})$.

\section{RESULTS AND DISCUSSION}

The results of transport $\mathrm{PM}_{10}$ emission models parameter sensitivity analysis and testing of $4 \mathrm{PM}_{10}$ emission mitigation policies are discussed in this section.

\section{A. Parameter Sensitivity analysis}

Parameters that have the strongest influence on $\mathrm{PM}_{10}$ concentration were determined during the parameter sensitivity test (see Fig. 4). This test is implemented by experimenting with different parameter values:

1. Baseline;

2. number of vehicles reduced by $20 \%$;

3. $\mathrm{PM}_{10}$ settling speed increase by $20 \%$;

4. heavy vehicle share increased by $20 \%$;

5. re-suspension emission rate reduction by $20 \%$;
6. tire and brake wear emission factor increase by $20 \%$;

7. vehicle exhaust emission increase by $20 \%$.

The results of the analysis of parameter sensitivity are illustrated in Fig. 4. Figure 4 shows that changing parameters as described in the results of scenarios e) and f) are almost the same as the baseline scenario (1). Thus it can be concluded that the influence of changes in emission factors from the exhaust gases, as well as tire and brake wear emission factors on $\mathrm{PM}_{10}$ concentrations is weak. The most sensitive parameters are the number of vehicles and re-suspension emission factors. Scenarios a) and d) (reduced number of vehicles and re-suspension emissions) are the furthest from the basic scenario; however they are very similar to one another their parameter sensitivity is similar. Changes in $\mathrm{PM}_{10}$ settling speed have slightly less impact on $\mathrm{PM}_{10}$ concentration. Changes in the share of heavy vehicles had an unexpectedly high impact on the system.

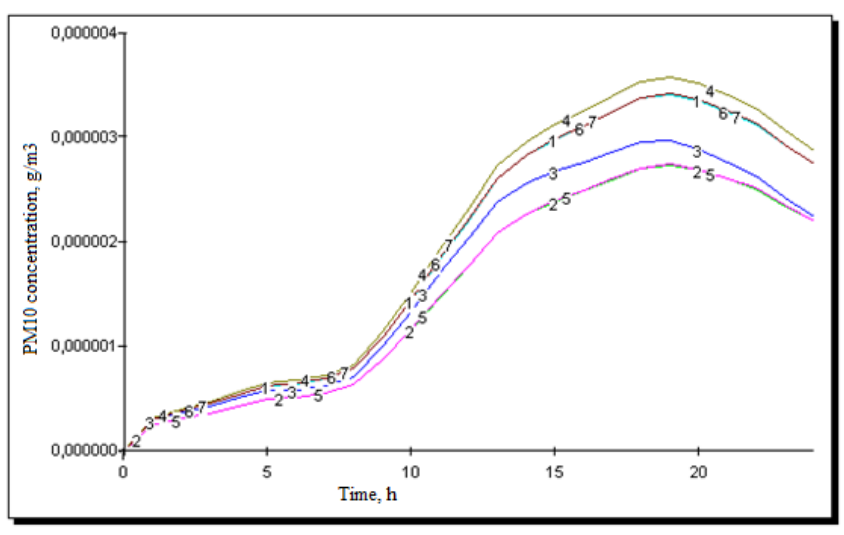

Fig. 4. Parameter sensitivity analysis

The results of the analysis of sensitivity are also useful for the development of $\mathrm{PM}_{10}$ mitigation policies, since they show which parameter change would give more significant results and which would be useless. In this case it is evident that, in order to reduce $\mathrm{PM}_{10}$ concentrations, pressure should be applied in order to reduce the number of vehicles and resuspension emission factors. Positive results can also be gained by $\mathrm{PM}_{10}$ acceleration of settling speed and reduction of heavy vehicle share in traffic.

\section{B. $P M_{10}$ mitigation policies}

Based on the analysis of the parameter sensitivity, three main points of force application were chosen: $\mathrm{PM}_{10}$ settling speed, re-suspension and the number of vehicles. $\mathrm{PM}_{10}$ concentration reduction tools can be divided into two groups:

1. Technological tools (road cleaning, wetting, use of chemical suppressants);

2. Administrative tools (traffic restrictions, air quality taxes).

Four different action policies were developed aiming to reduce $\mathrm{PM}_{10}$ concentration levels: 
Baseline scenario - baseline scenario reflects a situation where no measures to reduce the concentration of particulate matter are taken and the intensity of transport corresponds to the data from Riga City Council Traffic Department about the intersection at the streets of Brivibas - Tallinn on 4 November 2009.

Scenario A- The use of technological tools. Streets are being sprayed with CMA solution (25\% CMA and $75 \%$ water). Road surface are also cleaned mechanically once a month.

Scenario B - The use of administrative tools. Introduction of a fee for driving in a rush hour.

B1- Additionally to Scenario B, heavy traffic flows are diverted to the roundabouts of Riga (the proportion of heavy vehicles - 0,02).

Scenario C- A combination of both technological and administrative tools from scenarios A and B.

\section{Simulation results}

The pollution mitigation policies described in the previous section were simulated using the developed transport $\mathrm{PM}_{10}$ emission model. The simulation time is $24 \mathrm{~h}$. Simulation results $-\mathrm{PM}_{10}$ concentration changes during one day (24h) are shown in Fig.5.

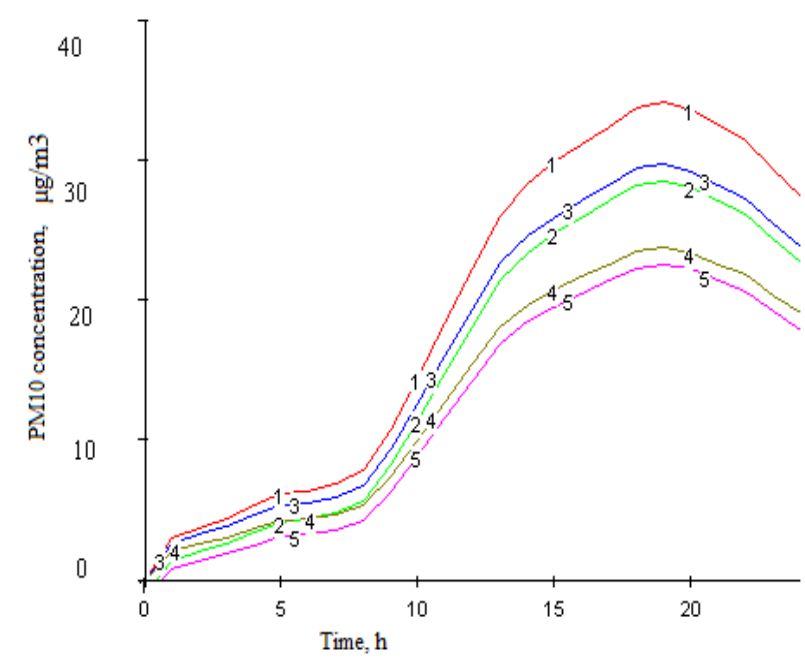

Fig.5. Simulation results: 1 - the baseline scenario; 2 - Scenario A, 3 Scenario B, 4 - Scenario B1, 5 - Scenario C

As seen in Figure 5, the highest daily $\mathrm{PM}_{10}$ concentration reduction is achieved in scenario $\mathrm{C}$, where both technological and administrative tools are applied. Total $\mathrm{PM}_{10}$ reductions in this scenario are $28.6 \%$ in comparison to the baseline scenario. The day's peak $\mathrm{PM}_{10}$ concentration decreases by $10 \mu \mathrm{g} / \mathrm{m} 3$. The second most effective is proved to be scenario $\mathrm{B} 1$, which combines a rush hour fee with heavy vehicle traffic restrictions. The diversion of heavy traffic on roundabout roads helps to reduce peak $\mathrm{PM}_{10}$ concentration by $5 \mu \mathrm{g} / \mathrm{m} 3$. Scenario B - only the introduction of a rush hour fee is much less efficient, in this case it would be more profitable to use the technological means as in scenario C. Since the difference between the efficiency of scenarios $\mathrm{C}$ and $\mathrm{B} 1$ is low and scenario $\mathrm{B} 1$ requires less routine maintenance work (assuming the urban agglomeration infrastructure allows a discharge of heavy vehicles on roundabouts), it would be advisable to investigate B1 scenario further including the cost - benefit analysis.

\section{CONCLUSIONS}

$\mathrm{PM}_{10}$ air pollution formation system from road transport is a large and complex system, with a number of parameters. The method of system dynamics is a useful tool for the assessment of transportation $\mathrm{PM}_{10}$ pollution and the testing of $\mathrm{PM}_{10}$ mitigation policy. Four $\mathrm{PM}_{10}$ mitigation policies were analyzed in this research along with the baseline scenario. It was determined that the most effective is scenario $\mathrm{C}$, where both administrative and technological $\mathrm{PM}_{10}$ pollution mitigation tools are used. Scenario B1 (only administrative $\mathrm{PM}_{10}$ mitigation methods - rush hour fee and heavy vehicle traffic restrictions) was the second most effective. Peak $\mathrm{PM}_{10}$ concentration in scenarios $\mathrm{C}$ and B1 differs only by $5 \mu \mathrm{g} / \mathrm{m}^{3}$, therefore it would be useful to carry out the cost-benefit analysis of these policies to decide which one is more appropriate for Riga.

The developed model of transport $\mathrm{PM}_{10}$ emission can be used to assess $\mathrm{PM}_{10}$ concentration for streets with different characteristics. In order to get more realistic results, the model should be supplemented with data about the effects of braking, acceleration and the driver's driving style on break and tire wear.

By supplementing the model with economic parameters and weather data, it can be used for cost-benefit analysis of $\mathrm{PM}_{10}$ mitigation policies or to determine in which weather conditions or at what time the methods of pollution mitigation should be introduced.

\section{REFERENCES}

1. Modal Split of freight transport according to the territoriality principle. Eurostat Statistic in Focus, 13/2012.- Luxembourg: Eurostat.Available online on: http://epp.eurostat.ec.europa.eu/ cache/ITY OFFPUB/KS-SF12-013/EN/KS-SF-12-013-EN.pdf [25.04.2013.]

2. Overview of the air quality in Latvia 2011. LVGMC. Available online: http://www.meteo.lv/fs/CKFinderJava/userfiles/files/Vide/Gaiss/Gaisa_k valitate/Parskati/parskats_par_gaisa_kvalitati_Latvija\%20_2011_gada.pdf [25.04.2013.]

3. The contribution of transport to air quality. TERM 2012: transport indicators tracking progress towards environmental targets in Europe. EEA Report, $\quad \mathrm{N}^{\circ} 10 / 2012 .-\quad 96$. Available online: www.eea.europa.eu/publications/transport-and-air-quality-term2012/.../file [11.05.2013.]

4. Querol, X., Alastuey, A., Moreno, T. et al. Spatial and temporal variations in airborne particulate matter $\left(\mathrm{PM}_{10}\right.$ and $\left.\mathrm{PM}_{2.5}\right)$ across Spain. Atmospheric Environment 42 (2008), 1999-2005.

5. Gualtieri, M., Rigamonti, L., Galeotti, V., Camatini, M. Toxicity of tire debris extracts on human lung cell line A549. Toxicology in Vitro, Volume 19 (7),2005.- 1001-1008.

6. Kupiainen, K., Tervahattu, H., Raisanen, M.et.al. Size and composition of airborne particles from pavement wear, tires, and traction sanding. Environmental Science \& Technology, 39 (2005). - 699-706.

7. Mathissen, M., Scheer, V., Vogt, R., Benter, T. Investigation on the potential generation of ultrafine particles from the tire - road interface. Atmospheric Enviroment, 45 (2011).- 6172-6179.

8. Kupiainen, K., Tervahattu, H., Raisanen, M. Eksperimental studies about the impact of traction sand on urban road dust composition. The Science of the Total Environment 308, (2002) 175-184.

9. Snilsberg, B., Myran, T., Uthus, N. The influence of driving speeds and tires on road dust properties: Snilsberg B. Pavement wear and airborne 
dust pollution in Norway. Characterization of the physical and chemical properties of dust particles. Doctoral Theses at NTNU, 2008. - 232. -248.

10. Vadlīniju sagatavošana transportlīdzeklu radītā PM10 un PM2,5 piesārnojuma modelēšanai Latvijas apstākļos. Project report (in Latvian)Riga Technical University, Riga, 2008,-- 21.

11. Kuhns, H., Etyemezian, V., Green, M. et.al. Vehicle-based road dust emission measurement. Part II: effect of precipitation, wintertime road sanding, and street sweepers on inferred $\mathrm{PM}_{10}$ emission potentials from paved and unpaved roads.// Atmospheric Environment, 37 (2003).- 45734582

12. Yan, F., Winijkul, E., Jung, S. et.al. Global emission projections of particulate matter (PM): I. Exhaust emissions from on-road vehicles// Atmospheric Environment, Volume 45, Issue 28, 2011.P.- 4830-4844.

13. Forrester, J. W. Industrial dynamics: a major breakthrough for decision makers.// Harvard business review, 36 (4) (1958)

14. Mavrommati, G., Bithas, K., Panayiotidi, P. Operationalizing sustainability in urban coastal systems: A system dynamics analysis//Water Research, Volume 47, Issue 20,15 2013, Pages 7235-7250

15. Marzouk, M., Azab, S. Environmental and economic impact assessment of construction and demolition waste disposal using system dynamics //Resources, Conservation and Recycling, Volume 82, J 2014, Pages 41-49

16. Habilomatis,

G.,

Chaloulakon,

A. Ultrafine particles dispersion modeling in a street canyon: Development and evaluation of a composite lattice Boltzmann model //Science of The Total Environment, Volumes 463-464, 2013, Pages 478-487

17. Dah,I E. Aerosols Physical Charasteristics.- State University of New York: Collage of Environmental Science and Forestry, 2008.

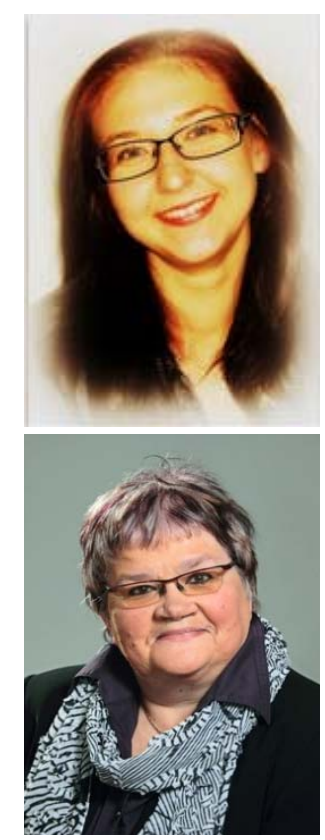

Dzintra Slišāne, B.sc., Riga Technical University, Environment Protection and Heating Systems Institute, there she obtained Bachelor's degree in Environmental Science. Her thesis was: „Assessment of roadside particulate emission mitigation possibilities ". She works in the Institute of Energy Systems and Environment, Riga Technical University from the year 2012 .

Address: Kronvalda boulev.1, LV1010, Riga, Latvia

E-mail: dzintra.slisane_1@rtu.lv

Dagnija Blumberga, Dr.hab.sc.ing., professor, Riga Technical University, Environment Protection and Heating Systems Institute. She has Thermal Engineer Diploma (1970) and two steps doctoral degree Condensing Unit" was defended in Lithuanian Energy Institute, Kaunas (1988). Doctor Habilitus Thesis "Analysis of Energy Efficiency from Environmental, Economical and Management Aspects" was prepared in Royal Institute of Technology (KTH) Stockholm (1995) and was defended in Technical University (1996).

Faculty of Energy and Electronics, Riga

Professor Dagnija Blumberga has been part of academic staff of Faculty of Energy and Electrotechnics, Riga Technical University since 1976 and director of Institute of Environmental Protection and Energy Systems since 1999.

The main research area is renewable energy resources. She has participated in different local and international projects related to energy and environment as well as is author of more than 200 publications and 14 books.

Address: Kronvalda boulevard 1, LV-1010, Riga, Latvia

Phone: +371 67089908

E-mail: dagnija.blumberga@rtu.lv 